\title{
Ghost Ant, Tapinoma melanocephalum (Fabricius) (Insecta: Hymenoptera: Formicidae) ${ }^{1}$
}

\author{
J. C. Nickerson, C. L. Bloomcamp and T. R. Fasulo²
}

\section{Introduction}

The ghost ant, Tapinoma melanocephalum (Fabricius), was considered a nuisance ant that was occasionally important as a house pest within Florida as late as 1988. Field populations were confined to South Florida although active colonies had been reported as far north as Gainesville, in Alachua County (Bloomcamp and Bieman, personal communication) and Duval County, (Mattis et al. 2004). But by 1995, if not before, the ghost ant was common in central and southern Florida and had been elevated to major pest status (Klotz et al. 1995). In more northerly states, infestations are confined to greenhouses or other buildings that provide conditions necessary for survival, as the ant is a tropical species either of African or Oriental origin (Wheeler 1910). However, this introduced ant species is so widely distributed by commerce that it is impossible to determine its original home (Smith 1965).

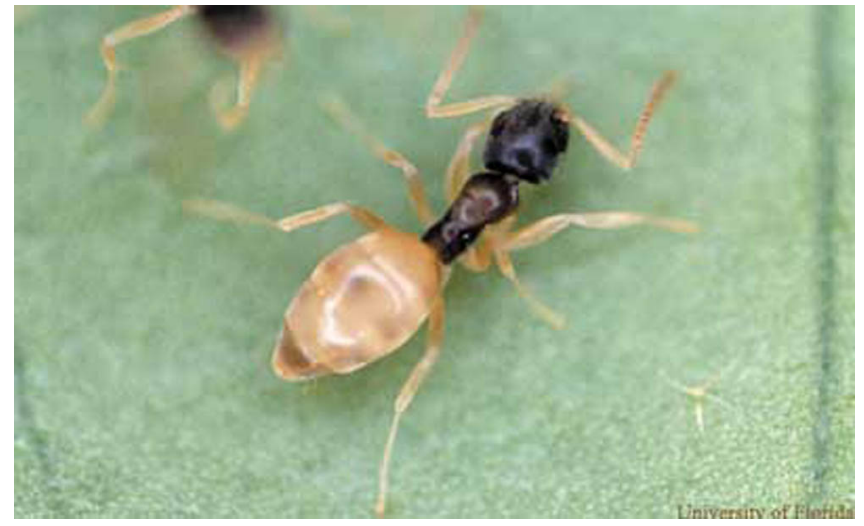

Figure 1. Worker of the ghost ant, Tapinoma melanocephalum (Fabricius). Credits: J.L. Castner, University of Florida

\section{Distribution}

The ghost ant is associated with a complex of ant species known as "tramp ants" that is widely distributed in tropical and subtropical latitudes worldwide. In fact, T. melanocephalum was once referred to simply as the "tramp ant." Colonies of $T$. melanocephalum are reported from such isolated locations as the Galapagos Islands (Clark et al. 1982). In temperate latitudes, the ghost ant is reported

1. This document is EENY-310 (originally published as DPI Entomology Circular 307), one of a series of Featured Creatures from the Entomology and Nematology Department, Florida Cooperative Extension Service, Institute of Food and Agricultural Sciences, University of Florida. Published: October 2003. This document is also available on Featured Creatures Website at http://creatures.ifas.ufl.edu. Please visit the EDIS Website at http://edis.ifas.ufl.edu. Additional information on these organisms, including many color photographs, is available at the Entomology and Nematology Department website at http://entnemdept.ifas.ufl.edu/.

2. Florida Department of Agriculture and Consumer Services, Division of Plant Industry; and T.R. Fasulo, Department of Entomology and Nematology, University of Florida, Gainesville, FL.

The Institute of Food and Agricultural Sciences (IFAS) is an Equal Opportunity Institution authorized to provide research, educational information and other services only to individuals and institutions that function with non-discrimination with respect to race, creed, color, religion, age, disability, sex, sexual orientation, marital status, national origin, political opinions or affiliations. U.S. Department of Agriculture, Cooperative Extension Service, University of Florida, IFAS, Florida A. \& M. University Cooperative Extension Program, and Boards of County Commissioners Cooperating. Larry Arrington, Dean 
established in greenhouses and other buildings with favorable conditions, even as far north as Winnipeg, Manitoba, Canada, where a colony nested in an apartment block on the Assiniboine River (Ayre 1977). Ghost ants populations and infestations are reported in many areas of the United States, as well as in Canada, Puerto Rico and the Caribbean Islands.

In the United States, the ghost ant is well established in Florida and Hawaii, and its range is expanding. The ant reached Texas in 1994 or 1995, probably through Galveston on a shipment of plants from Florida (Chenault 1997). In the northern states, it can only survive in greenhouses and other heated environments (Smith and Whitman 1992).

In Florida, the ghost ant is mostly found from Sarasota to Orlando and south, although it does occur as far north as Gainesville in Alachua County (Beauchamp 1997, Klotz et al. 1995), and Duval County (Mattis et al. 2004).

A survey conducted with Florida structural pest control employees to determine the kinds of ants and types of ant problems confronted in both commercial and household pest control revealed that eight species of ants were identified as key pests in Florida. Of these, the most common were the red imported fire ant, Solenopsis invicta Buren, the ghost ant, Tapinoma melanocephalum, (Fabricius); and the crazy ant, Paratrechina longicornis (Latreille). Each species comprising $14 \%$ of the samples submitted (Klotz et al. 1995).

\section{Description}

Ghost ant workers are extremely small, 1.3 to 1.5 $\mathrm{mm}$ long and monomorphic (one-sized). They have 12-segmented antennae with the segments gradually thickening towards the tip. Antennal scapes surpass the occipital border. Head and thorax are a deep dark brown with gaster and legs opaque or milky white (Creighton 1950). The thorax is spineless.

The gaster (swollen part of abdomen) has a slit-like anal opening which is hairless. (Smith and Whitman 1992). The abdominal pedicel (stalk-like structure immediately anterior to the gaster) consists of one segment which is usually hidden from view

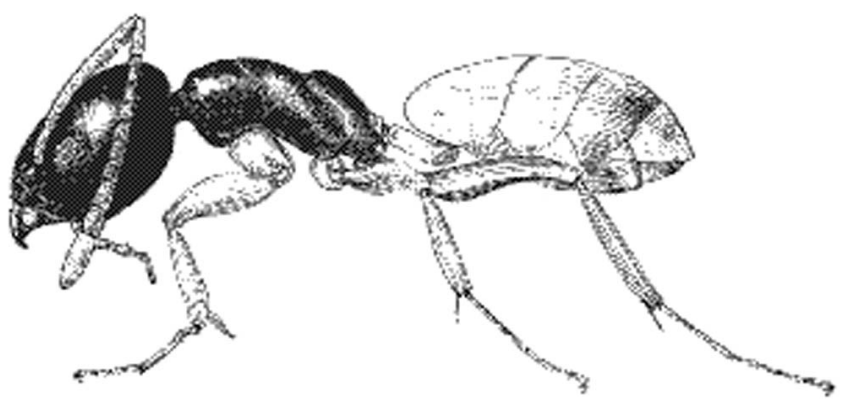

Figure 2. Ghost ant worker.

dorsally by the gaster (Creighton 1950). Stingers are absent.

The small size, combined with the pale color, make ghost ant workers hard to see (Smith and Whitman 1992).

\section{Biology and Behavior}

The ghost ant is highly adaptable in its nesting habits. It nests readily outdoors or indoors. Colonies may be moderate to large in size containing numerous reproducing females (polygyny). Generally, the colonies occupy local sites that are too small or unstable to support entire large colonies. The sites include tufts of dead but temporarily moist grass, plant stems, and cavities beneath detritus in open, rapidly changing habitats (Oster and Wilson 1978). Indoors, the ant colonizes wall void or spaces between cabinetry and baseboards. It will also nest in potted plants (Smith and Whitman 1992). Thus, the colonies are broken into subunits that occupy different nest sites and exchange individuals back and forth along odor trails (Oster and Wilson 1978). Hölldobler and Wilson (1990) report that ghost ants are opportunistic nesters in places that sometimes remain habitable for only a few days or weeks

Multiple queens may be spread out in multiple subcolonies. Usually, nesting occurs in disturbed areas, in flowerpots, under objects on the ground, under loose bark, and at the bases of palm fronds. Indoors, the ant nests in small spaces such as cracks, spaces between books, or wall voids. Indoor foragers often come from outside. This is a very common pest inside homes (Ferster et al. 2002).

New colonies are probably formed by budding. This occurs when one or more reproductive females, accompanied by several workers and possibly some 
brood (larvae and pupae) leave an established colony for a new nesting site. There does not appear to be any infighting between members of different colonies or nests (Smith and Whitman 1992).

The nesting habits of the ghost ant are similar to that of the Pharaoh ant, Monomorium pharaonis (Linnaeus) (Smith and Whitman 1992).

Workers have the habit of running rapidly and erratically when disturbed. They are fond of honeydew and tend honeydew-excreting insects. They also feed on both dead and live insects (Smith 1965). When workers are found trailing, their movement is more slow and deliberate. On close inspection some trailing workers can be seen carrying brood (larvae and pupae) (Ferster et al. 2002). They will enter structures from nests near foundations or from plants that contact the building (Smith and Whitman 1992).

In Costa Rica, jumping spiders (Araneae: Salticidae) were found living within nests of $T$. melanocephalum located on the undersides of leaves. The basis of this relationship appears to be symbiotic. The spiders provide the ants with protection from predators and parasites, while the ant nest is used as a foundation for web construction (Shepard and Gibson 1972).

\section{Economic Importance}

This species is a household pest. In Florida, it is considered one of the most important of such ant pests. The ghost ant can not only invade houses from outside, but they can nest in the house as well. Although the ant feeds upon many household foods, it seems to show a preference for sweets, having been observed feeding on sugar, cakes, and syrups (Smith 1965). Outside, the workers scavenge for dead insects and tend sap-sucking insects, collecting honeydew (Ferster et al. 2002).

In Florida, the ghost ant has infested quarantine greenhouses where they have proven impossible to control due to the restrictions imposed on the use of toxicants in these greenhouses. In Gainesville, the ant preyed upon small beetle larvae and lepidopterous larvae from the cultures of insects in quarantine. In more northern areas, it has become established in heated greenhouses where it can become a problem, especially if it defends honeydew producing, plant pests against introduced biological control organisms.

In coastal Venezuela, the ghost ant was found to be the primary predator of the eggs of Rhodnius prolixus, the vector of Chagas' disease. This effective predaceous activity on $R$. prolixus populations by $T$. melanocephalum may account for the absence of $R$. prolixus associated diseases from this area of Venezuela (Gomez-Nunez 1971).

\section{Detection}

The ant is easily recognized due to its peculiar color markings and small size. Foragers are seen in kitchens and bathrooms on sinks, counters, and floors. When crushed, the workers emit an odor similar to that of rotten coconuts (Smith 1965).

The ghost ant is in the same genus as the odorous house ant, Tapinoma sessile (Say). However, the ghost ant is smaller and colored differently since the odorous house ant is entirely dark brown to black.

The Pharaoh ant is also similar to this species but the ghost ant only has one node on its pedicel compared to two on the pedicel of the Pharaoh ant. Other bi-colored, one-node ants either tend to be much larger or the node on the pedicel is visible from above (Smith and Whitman 1992).

\section{Management}

The best approach to ant control in the home is cleanliness. Any type of food or food particles can attract and provide food for ants. Store food in tight containers. Remove plants that can attract ants or control aphids, whiteflies and other insects that produce honeydew. Reduce moisture sources, including condensation and leaks (Koehler and Oi 2002).

If possible, follow the trails of this species back to the next and treat the nest. If treating the trails with bait check within one or two days to see if the ants are feeding. If not, relocate the bait. (Smith and Whitman 1992). Indoor colonies nesting within voids can be controlled with baits. Access of foragers entering from outdoors through cracks and crevices or screens 
should be restricted with barrier sprays (Ferster et al. 2002).

Generally, control is not necessary except where it becomes a nuisance in the home or in greenhouses. If control is necessary, the ant is susceptible to a number of insecticides used in baits or as contact poisons. The latest recommendations are available in the UF/IFAS Insect Management Guide at:

Insect Management Guide for Ants (http://edis.ifas.ufl.edu/IG080)

Ant Trails: a Key to Management with Baits (http://edis.ifas.ufl.edu/IG123).

\section{Selected References}

Ayre GL. 1977. Exotic ants in Winnipeg, Manitoba. Entomologist 11: 4111-4144.

Beauchamp S. (October 1997). Ghost ants can be more trick than treat for homeowners. UF/IFAS News Release. http://news.ifas.ufl.edu/story. php?id=89 (25 September 2003).

Chenault, EA. 1997. Ghost ants now in Texas. Texas A\&M Agriculture News. http://agnews. tamu.edu/dailynews/stories/ENTO/Feb2697a.htm (22 September 2003).

Clark DB, Guayasamin C, Pazmino O, Donoso C, Paez de Villacis Y. 1982. The Tramp ant Wasmannia auropunctata: Autecology and effects on ant diversity and distribution on Santa Cruz Island, Galapagos. Bio-tropica 14: 196-201.

Creighton WS. 1950. The ants of North America. Bulletin of the Museum of Comparative Zoology 104: 13-585, 57 pl.

Ebeling W. 1978. Urban Entomology. Agricultural Sciences Publications, University of California, Berkeley, CA.

Ferster B, Deyrup M, Scheffrahn RH, Cabrera BJ. (2002). The pest ants of Florida. http://flrec. ifas.ufl.edu/entomo/ants/Pest $\% 20$ Ants $\% 20 \mathrm{of} \% 20 \mathrm{FL} /$ (12 September 2003).
Gomez-Nunez JC. 1971. Tapinoma melanocephalum as an inhibitor of Rhodnius prolixus populations. Journal of Medical Entomology 8: 735-737.

Haack KD, Granovsky TA. (1990). Ants. In Handbook of Pest Control (Story K, Moreland D. (eds.)). Franzak \& Foster Co., Cleveland, OH. pp. 415-479.

Hölldobler B, Wilson EO. 1990. The Ants. Belknap Press of Harvard University Press. Cambridge, MA. 732 pp.

Klotz JH, Mangold JR, Vail KM, Davis Jr LR, Patterson RS. 1995. A survey of the urban pest ants (Hymenoptera: Formicidae) of peninsular Florida. Florida Entomologist 1: 109-118.

Klotz J, Williams D, Reid B, Vail K, Koehler P. (September 2000). Ant trails: a key to management with baits. EDIS. http://edis.ifas.ufl.edu/IG123 (29 May 2003).

Koehler PG, Oi FM. (October 2002). Ants. UF/IFAS Insect Management Guide. http://edis.ifas.ufl.edu/IG080 (25 September 2003).

Koehler PG, Short DE, Fasulo TR. (2002). Pests In and Around the Home. UF/IFAS. SW-126. CD-ROM.

Mattis P, Zerba Jr R, Bennett C. 2004. Pest of the month. Commercial Clippings 7(2):3.

Oster GF, Wilson EO. 1978. Caste and ecology in the social insects. Princeton University Press, Princeton, New Jersey. 352 p.

Shepard M, Gibson F. 1972. Spider-ant symbiosis: Cotinusa spp. (Araneida: Salticidae) and Tapinoma melanocephalum (Hymenoptera: Formicidae). Canadian Entomologist 104: 1951-1954.

Smith EH, Whitman RC. 1992. Field Guide to Structural Pests. National Pest Management Association, Dunn Loring, VA.

Smith MR. 1965. House-infesting ants of the eastern United States; their recognition, biology, and economic importance. USDA-ARS Technical Bulletin 1326. 105 p. 
Wheeler WM. 1910. Ants, their structure, development and behavior. Columbia University Press. New York and London. 663 p. 